\title{
Awareness on Vaccinations among Chronic Kidney Disease Patients in Rural India
}

\section{IJCRR \\ Section: Healthcare \\ Sci. Journal Impact \\ Factor: 6.1 (2018) \\ ICV: 90.90 (2018) \\ (c) (7) (8) \\ Copyright@IJCRR}

\section{Deepali Ghungrud ${ }^{1}$, Ranjana Sharma²}

\begin{abstract}
'Nursing Student, Department of Medical-Surgical Nursing, Smt. Radhikabai Meghe Memorial College of Nursing, Datta Meghe lnstitute of Medical Sciences (Deemed to be University), Sawangi (Meghe) Wardha, Maharashtra, India; ${ }^{2}$ Associate Professor, Department of Medical-Surgical Nursing, Smt. Radhikabai Meghe Memorial College of Nursing, Datta Meghe Institute of Medical Sciences (Deemed to be University), Sawangi (Meghe) Wardha, Maharashtra, India.
\end{abstract}

\section{ABSTRACT}

Chronic Kidney Disease" also known as a chronic renal failure, is one of the major health problems today. The main function of the kidney in the human body is to filter the waste products of the human body and excrete the same in the form of urine. Infectious diseases are the second leading cause of morbidity and mortality in patients with chronic kidney disease, contributing around $30-36 \%$ of deaths among patients on dialysis. Overall, this condition is a threat to the life of the patients, hence to improve in the patient's condition dialysis and renal replacement therapy is a must. But before the onset of dialysis and renal replacement therapy, here, early vaccination becomes must as a primary treatment modalities to prevent patients from nosocomial infections i.e. hospital-acquired infection like Hepatitis-B, Influenza, Pneumococcal diseases, these are the common diseases due to such infection and their prevalence rate is high in India as compared to others diseases. Therefore, to prevent the patients from any such risk early vaccination is needed. This review aimed to access this information for educating the patients regarding the importance of vaccination before the onset of dialysis and renal transplantation, to suggest that this vaccine should be available at various private and government hospitals at low prices than its original price and to evaluate the effectiveness of the awareness program on vaccinations among chronic kidney disease patients. Here the problem is that many patients belonging to lower socioeconomic status can not afford this costly vaccine and many patients are not aware of this vaccination needed in chronic kidney disease before starting of dialysis, because of lack of education or no any such information received from health care professionals. Hence it's essential to create awareness regarding vaccination among chronic kidney disease patients to reduce morbidity and mortality.

Key Words: Chronic kidney disease, Hospital-acquired infection, Hepatitis B, Influenza, Pneumococcal, Patient, Vaccination

\section{INTRODUCTION}

Infection is the second major common cause of morbidity and mortality among patients with chronic kidney disease in India, contributing up to $30-36 \%$ of deaths among patients on dialysis, these patients are very susceptible to any kind of infection, which results in patient's low immunity power and patients came in immune deficiency stage. Such patients show manifestations like abnormal phagocytosis, $\mathrm{T}$ and $\mathrm{B}$ lymphocytes, they mostly suffer from septicemia and pulmonary infectious diseases. In chronic kidney disease, most of the patients died because of an infection, the mortality is high in chronic kidney disease population due to Hepatitis-B, pulmonary infection and influenza as compared to the general population. ${ }^{1-3}$
Immunization is a must against common infectious disease like Hepatitis-B, pneumococcal diseases and influenza. Influenza spreads every year, but in different strength and hence every year vaccination is needed in chronic kidney disease patients and also should be taken by healthy individuals for avoiding further risk. Chronic kidney disease patients having low antibody response to vaccine indicate the degree of renal failure. ${ }^{4,5}$

So, this highlights that these vaccines are must be needed for chronic kidney disease population as compared to other medical intervention. Vaccination in chronic kidney disease population saves more lives, hence the practice of vaccination for chronic kidney disease patients in hospital is necessary. Infections increase hospital stay among chronic kidney disease patients. Nephrologists, health care professionals are

\section{Corresponding Author:}

Deepali Ghungrud, Smt. Radhikabai Meghe Memorial College of Nursing, Datta Meghe Institute of Medical Sciences, (Deemed to be University), Sawangi (Meghe) Wardha, Maharashtra, India; Email: ghungruddeepali@gmail.com

ISSN: 2231-2196 (Print)

Received: 25.06 .2020
ISSN: $0975-5241$ (Online)

Revised: 24.08 .2020
Accepted: 04.10 .2020
Published: 12.11 .2020 
taking the initial step to participate in awareness programs and create awareness among chronic kidney disease population regarding vaccination by using educational methods and media. All these steps are very essential for the good prognosis of patients with chronic kidney disease.,

\section{PREVALENCE AND INCIDENCE OF CANTA- GIOUS DISEASE IN CHRONIC KIDNEY DIS- EASE}

\section{Chronic kidney disease}

In patients taking treatment for chronic kidney disease it was found that near about $35 \%$ of infection is related to hospitalizations. The occurrences of the hepatitis B infections are very high in dialysis patients, at about $7.6 \%$ and $3.2 \%$, respectively in India. ${ }^{7,8}$ Mortality of patients with chronic kidney disease is higher due to Pneumonia, it is 14 to 16 -fold higher than the general population. It has a global incidence of 1.5-14 per 1000 person-years, pneumonia-related treatment. Pneumonia related treatment focuses on the heavy monitory burden to healthcare..$^{5-8}$ Mostly age group of 46-60 years got affected by Influenza disease, especially males got more affected with $50.6 \%$. The signs and symptoms suggested that fever with cough $(89.6 \%)$ followed by shortness of breath $(72.7 \%)$ are the most common symptom. Most of the cases are reported in post-monsoon season, so it can be considered as peak period., ${ }^{7,8}$ Patients with chronic kidney disease admitted in the hospital are having more chances of hospital-acquired infection i.e nosocomial infection as compared to the general population. Because they had undergone different investigation procedures during dialysis and renal replacement therapy. There is no particular data available which will disseminate that chronic kidney disease is a stage-specific infection. ${ }^{5,7,8}$ While treating patients who receive maintenance dialysis, we found that infection is a primary issue behind this.

\section{MODE OF TRANSMISSION}

\section{Hepatitis}

Patients undergoing treatment for chronic kidney disease got hospitalized many times during dialysis and renal replacement therapy which forced them to undergo different procedures like blood investigation, exposure of blood products, blood transfusion, unhygienic practices during handling of hemodialysis patients, reuse of dialyser and dialysate, crosscontamination from environmental surfaces, in that condition Hepatitis-B infection can be transmitted by infected blood in chronic kidney disease patients are shown in Figure 1 , which increases chances of infection and disease, therefore to prevent patients from contagious disease early vac- cination is needed..$^{9-11}$

\section{Influenza}

Patients under dialysis, who shows influenza signs are at high risk for complications, which includes hospitalization and death. Patients should receive influenza vaccine usually in the winter. The mode of transmission of influenza primarily is by Person to person contact, coughing and sneezing, surface contaminated by respiratory secretions, talking and breathing can disperse the flu virus are shown in Figure 2. Symptoms of flu can be identified as headache and body aches, high fever, sore throat, fatigue also a runny nose. A flu infection is very serious for people having a low immune system. ${ }^{11,12}$

\section{Pneumococcal Disease}

Pneumococcal diseases are secondary common infection in the final stage of kidney disease population after infection of the bloodstream and it is related to increased mortality. The pneumococcal disease spreads by droplets i.e sneezing, coughing. Its infection in the lungs can cause pneumonia i.e inflammation of lungs. It enters in the bloodstream and can cause blood infection i.e septicemia and leading to poor blood flow because of which organ gets damaged, this is shown in Figure 3. The incubation period of pneumococcal pneumonia is short of 1-3 days. ${ }^{12}$

\section{EPIDEMIOLOGY}

\section{Chronic kidney disease}

Very few studies are available on the prevalence of infections in chronic kidney disease population. There are no particular data available which will disseminate that chronic kidney disease is stage-specific infection. But the hospitalized patients are having more chances of hospital-acquired infection as compared to other patients because they undergo different investigation procedures during dialysis and renal replacement therapy. ${ }^{13-15}$

\section{Renal disease at End stage}

Acute infection is a common cause of hospitalization most of the time among the patients with end-stage renal disease and due to this infection hospital stay increases for patients. ${ }^{14,15}$

\section{NEED FOR AN AWARENESS PROGRAM}

Sometimes patients have no medium available to access the information, sometimes patients receive 2 or 3 Hepatitis B doses but he does not complete the course. On clinical observation, it was found that many patients complete Hepatitis$B$ vaccination course but have not completed the doses of 
pneumonia and influenza vaccine because of its high cost. Complete vaccine dose charges are not affordable to many patients and even many of them don't know exactly where they should receive the vaccine. By the time due to all these reasons patients on dialysis prone to get the infection and it gets converted into complications like liver carcinoma, liver failure, septicemia, pneumonia etc. Our motive is to avoid all these things, patients should get proper information and quality life. ${ }^{16}$

\section{FINANCIAL BURDEN OF VACCINATION}

The average cost of complete doses of patients with chronic kidney disease vaccination is too high, and as most of the patients visiting hospital belong to lower socio-economical status, that's why they can not afford all the doses of vaccine and as a result vaccine dose cycle does not gets completed. In such cases, there are high chances of patients getting infected and due to infection morbidity and mortality will again increase among the chronic kidney disease patients. ${ }^{13,17}$ Average cost of full doses of recommendations for all vaccinations in adult patients suffering from chronic kidney disease is mentioned in Table 1.

\section{Need for Vaccination amongst health care em- ployees and caregivers}

Hepatitis-B vaccines are necessary for health care personnel because they always come in contact with these patients and if chronic kidney disease patients will be positive for the infectious disease so it will easily transmit to health care employees also, so before coming in contact with a patient with chronic kidney disease with contagious disease vaccination amongst health care professionals is must. Other vaccines i.e Varicella, influenza etc are needed in most of the centres and it results in decreased nosocomial i.e infection occurred at the hospital. All these inactivated or killed vaccines are most important and are safer for health care employees and family members in close contact with renal transplantation patients. ${ }^{18-20}$

\section{Preventive strategies}

The prevention strategies are always better instead of curing the disease. Vaccination status, maintenance of ideal vaccination status is needed in chronic kidney disease. Always ideally vaccinate the patients before going to transplantation and before dialysis. Though they did not receive vaccination they can also receive afterwards. Vaccines which are inactivated are generally safe after kidney transplantation. ${ }^{14,15}$ Live vaccines can not be administered after transplantation. Hence it is proper to implement the vaccines which are living at least 1 month before transplantation, these vaccines are easily available and the cost of the vaccine is also low. There are various types of live and killed vaccines which are available for chronic kidney disease patients before dialysis and transplantation, which are important for 3 diseases viz. Hepatitis-B, Pneumococcal diseases and influenza. In all these three diseases, the prevalence rate is very high in India and mortality is also increasing. ${ }^{16-20}$ Health workers, closed family members and other closed contact persons of patients are very important to be fully immunized. Make sure that everyone should take the influenza vaccine every year. ${ }^{21-23}$

\section{RECOMMENDATION OF VACCINATION}

Numerous vaccines are available on chronic kidney disease/ renal replacement therapy patients, but most popular vaccines which are in practice in India are-

\section{Hepatitis-B Vaccine}

The patients should receive four doses of hepatitis B vaccine as early as possible in the course of the disease. Doses schedule should be $0,1,2$, and 6 months. Hepatitis-B vaccine should be given $2 \mathrm{ml}$ (40 IU) Intramuscular in deltoid muscles. ${ }^{22-}{ }^{24}$ There is no adverse effect found Hepatitis-B vaccine guidelines are shown in Table 2.

\section{Influenza Vaccine}

0.5 ML (Intramuscular) in detailed muscle stat dose once in a year. ${ }^{21-24}$

\section{Pneumococcal vaccine}

The guidelines for the administration of pneumococcal conjugate vaccine-13 (PCV 13) and pneumococcal polysaccharide vaccine 23 (PPSV 23) in patients with chronic kidney disease are mentioned in Table 3.Vaccine administered in deltoid muscle stat is $0.5 \mathrm{ml}$ (Intramuscular). No adverse effect was found..$^{23,24}$

\section{Measles, mumps and rubella vaccine}

These are live vaccine and these vaccines are preferred after renal transplant. Very necessary in all patients of prospective paediatric. $^{8,23,24}$

\section{Varicella vaccine}

Varicella is a live attenuated vaccine and it is contraindicated after renal replacement therapy.it is recommended all considered paediatric patients and also adolescent transplant Patients. ${ }^{19,20}$

\section{Polio vaccine}

Polio vaccine given through mouth is a live vaccine and in the paediatric child. It is contraindicated in transplant recipients and their nearer contact persons. Therefore, Beneficiaries of pediatric transplants along with their family members are not included in regular polio vaccination programs. ${ }^{24}$ 


\section{Diptheria, pertussis and tetanus vaccine}

Killed vaccine i.e inactivate vaccines such as Diptheria, pertussis, and tetanus are recommended to all renal transplant recipients who are considered paediatric. A booster dose of Diptheria- tetanus only is recommended to Adult receipent. ${ }^{24}$ But out of all vaccines most important vaccination is needed in chronic kidney disease for an adult is Hepatitis-B, influenza vaccine and Pneumococcal vaccine because these three diseases prevalence rate is high in India as compared to other diseases. ${ }^{8}$ Here it is very important to note that, above all vaccines should be taken by patients on non-dialysis day and in the non-arteriovenous fistula arm.

\section{Travel vaccination}

If you are travelling overseas then vaccination is most essential particularly when the area where few infections are endemic, they need special consideration. Before travelling pre-planning is essential which includes a blood test for searching antibodies in a particular person's blood before starting the journey. ${ }^{20,25,26}$

BENEFITS OF PROPHYLACTIC VACCINATION AND PRIMARY PREVENTION Vaccinations have indicated a better survival rate of dialysis patients. ${ }^{8,9,20}$

1. Vaccination which will help to reduce morbidity and mortality in patients with chronic kidney disease. ${ }^{8,9,20}$

2. It helps to reduce recurrent Hospitalization. ${ }^{24}$

3. Positive results can be seen after vaccination in chronic kidney disease patients for renal transplantation and dialysis.

4. Vaccination helps to protect from Infections. ${ }^{14,15}$

5. Knowledge of vaccination is essential to treat chronic kidney disease patients effectively. ${ }^{6}$

6. Prognosis of the disease will be good.

\section{Prognosis}

Vaccination showed positive effects in chronic kidney disease patients and renal replacement therapy patients too before $1^{\text {st }}$ dialysis. Ideally, early vaccination can help in preventing many infections causing morbidity and mortality without any side effects ..$^{20,27,28}$

\section{PERSPECTIVE}

Vaccination is an important part of preventive treatment modalities for chronic kidney disease patients. Ideally, it should be received by chronic kidney disease patients before the onset of hemodialysis. ${ }^{8,20,23}$ Even though patients have not received it before the onset of dialysis, they can receive it afterwards but it necessary to complete the vaccination schedule as recommended by the Indian Journal of nephrology. ${ }^{8}$ If patients are immunized early risk of infection will reduce inpatients and patients response will be good for dialysis and ultimately it will result in a reduction in morbidity and mortality of a chronic kidney disease patients. ${ }^{20,23}$ After renal transplantation influenza vaccination is a must for these patients for preventing them from epidemic or pandemic diseases. For example in today's COVID -19 pandemic, a patient with chronic kidney disease, if not immunized with influenza then patients may have chances of pulmonary problems like pneumonia, septicemia and hence to prevent them from all such critical issues patients should receive all vaccines.

\section{CONCLUSION}

Proper Vaccination status will decrease infection issue and economical disease burden among chronic kidney disease patients. Vaccination helps to prevent Hepatitis-B viral infection to other family members also. Above all vaccines are recommended in the chronic kidney disease population. Therefore better practice by nephrologists and awareness of vaccination in chronic kidney disease at an early stage will reduce morbidity and mortality. So it is very important to educate people in general and to increase awareness on the importance of the preventive measures related to vaccination in chronic kidney disease patients before going to dialysis and renal replacement therapy. ${ }^{6}$ This literacy will help to develop awareness among the general population including peoples in low socioeconomic status. Therefore every institution, nephrologists, health care providers have a responsibility to make a proper policy regarding vaccination in chronic kidney disease, practice it and create awareness as primary and preventive care to prevent morbidity and mortality among chronic kidney disease population at large. ${ }^{6}$

\section{ACKNOWLEDGEMENT}

The Author thanks to Dr. Seema Singh, Professor, and Principal, Smt. Radhikabai Meghe Memorial College of Nursing. Datta Meghe Institute of Medical Sciences (Deemed to be University), Sawangi (Meghe) Wardha, Maharashtra India. for her timely support and valuable suggestions. The author also extended gratitude to Dr. Amol Bhawane, Assistant. Professor, Dept. of Nephrology, Acharya Vinoba Bhave Rural Hospital, Datta Meghe Institute of Medical Sciences (Deemed to be University), Sawangi (Meghe), Wardha, Maharashtra India, for their valuable suggestions and guidance.

Ethical approval: Ethical clearance, Taken from IEC-ref. no. DMIMS(DU)/IEC/Dec-2019/8688

Conflict of Interest: The author declares that there are no conflicts of interest.

Funding: Self 


\section{REFERENCES}

1. Dinits-Pensy M, Forrest GN, Cross AS, Hise MK. The use of vaccines in adult patients with renal disease. Am J Kid Dis 2005;46(6):997-1011.

2. Verma B, Singh A, Bishnoi JS, Mishra AK. Adherence to Medications in Chronic Kidney Disease: Prevalence, Predictors and Outcomes. Int J Cur Res Rev 2018;10(19):14-19.

3. Grzegorzewska AE. Prophylactic vaccinations in chronic kidney disease: current status. Hum Vaccin Immunother 2015;11(11):2599-2605.

4. Abdelsalam KE, Musllem EM. Influence of end-stage renal disease in alteration of some trace elements in Sudanese patients. Int J Cur Res Rev 2018;8(10):16-22.

5. Wilmore SM, Philip KE, Cambiano V, Bretherton CP, Harborne JE, Sharma A, Jayasena SD. Influenza and pneumococcal vaccinations in dialysis patients in a London district general hospital. Clin Kidney J 2014 ;7(1):27-32.

6. Akinbodewa AA, Adejumo OA. Awareness and Practice of Vaccination of Chronic Hemodialysis Patients by Specialist Nephrology Practitioners in Nigeria: A Cross-Sectional Survey. J Epidemiol Glob Heal 2019;9(3):204-209.

7. Amjad A, Kumar J, Chaudary N, Kumar K, Nazar CM, Khan K. Hepatitis B Vaccination Status in Chronic Kidney Disease: Experience at Pakistan Institute of Medical Sciences. Cureus 2019;11(7): e5282.

8. Guidelines for vaccination in patients with chronic kidney disease. Ind J Nephrol 2016; 26 (7): 15-8

9. National Kidney Foundation. 2015:1-14.

10. Gilbertson DT, Unruh M, McBean AM, Kausz AT, Snyder JJ, Collins AJ. Influenza vaccine delivery and effectiveness in endstage renal disease. Kidney Int 2003;63(2):738-743.

11. Duong MC, Nguyen VT, Otsu S, McLaws ML. Prevalence of hepatitis $\mathrm{B}$ and $\mathrm{C}$ virus infections in hemodialysis patients in Vietnam: A systematic review and meta-analysis. JGH Open 2020;4(1):29-38.

12. Krüger S, Müller-Steinhardt M, Kirchner H, Kreft B. A 5-year follow-up on antibody response after diphtheria and tetanus vaccination in hemodialysis patients. Am J Kidney Dis 2001;38(6):1264-1270.

13. Chou CY, Wang SM, Liang CC, Chang CT, Liu JH, Wang IK, Hsiao LC, Muo CH, Huang CC, Wang RY. Risk of pneumonia among patients with chronic kidney disease in outpatient and inpatient settings: a nationwide population-based study. Medicine 2014;93(27): e174

14. Dalrymple LS, Go AS. Epidemiology of acute infections among patients with chronic kidney disease. Cli J Am Soc Nephrol 2008;3(5):1487-1493.
15. Tandon BN, Acharya SK, Tandon A. Epidemiology of hepatitis B virus infection in India. Gut 1996; 38(Suppl 2): S56-S59.

16. Marinaki S, Kolovou K, Sakellariou S, Boletis JN, Delladetsima IK. Hepatitis B in renal transplant patients. World J Hepatol 2017 ;9(25): 1054-1063.

17. Ishigami J, Padula WV, Grams ME, Chang AR, Jaar B, Gansevoort RT, Bridges JF, Kovesdy CP, Uchida S, Coresh J, Matsushita K. Cost-effectiveness of pneumococcal vaccination among patients with CKD in the United States. Am J Kidney Dis 2019;74(1):23-35.

18. Grzegorzewska AE. Hepatitis B vaccination in chronic kidney disease: a review of evidence in non-dialyzed patients. Hepatitis Mon 2012;12(11): e7359.

19. Vaccination and patients with chronic conditions background report: Commissioned by the European Patients' Forum 2018:126.

20. Krueger KM, Ison MG, Ghossein C. Practical guide to vaccination in all stages of CKD, including patients treated by dialysis or kidney transplantation. Am J Kidney Dis 2020;75(3):417-425.

21. Bakkaloğlu SA, Atikel YO, Paglialonga F, Stefanidis CJ, Askiti V, Vidal E, et al. Vaccination Practices in Pediatric Dialysis Patients Across Europe. A European Pediatric Dialysis Working Group and European Society for Pediatric Nephrology Dialysis Working Group Study. Nephron 2018;138(4):280-286.

22. Gunawansa N, Rathore R, Sharma A, Halawa A. Vaccination practices in End-Stage Renal Failure and Renal Transplantation, Review of current guidelines and recommendations. World $\mathrm{J}$ Transplant 2018;8(3):68-74.

23. Hashemi B, Mahdavi-Mazdeh M, Abbasi M, HosseiniMoghaddam SM, Zinat NH, Ahmadi F. Efficacy of HBV vaccination in various stages of chronic kidney disease: is earlier better?. Hepatitis Mon 2011;11(10):816-820.

24. Janus N, Amet S, Rapuch-Zimner S, Deray G, Launay-Vacher V. Vaccination and chronic kidney disease. J de Pharmacie Clinique. 2010;29(3):149-157.

25. Aung AK, Trubiano JA, Spelman DW. Travel risk assessment, advice and vaccinations in immunocompromised travellers (HIV, solid organ transplant and haematopoietic stem cell transplant recipients): a review. Travel Med Infect Dis 2015;13(1):31-47.

26. Boggild AK, Sano M, Humar A, Gilman M, Salit I, Kain KC. Travel patterns and risk behaviour in solid organ transplant recipients. Journal of Travel Med 2004;11(1):37-43.

27. Kausz A, Pahari D. The value of vaccination in chronic kidney disease. In seminars in dialysis Oxford, UK: Blackwell Science Inc. 2004; 17(1):9-11.

28. Janus N, Amet S, Rapuch-Zimner S, Deray G, Launay-Vacher V. Vaccination and chronic kidney disease. Journal de Pharmacie Clinique. 2010;29(3):149-57. 


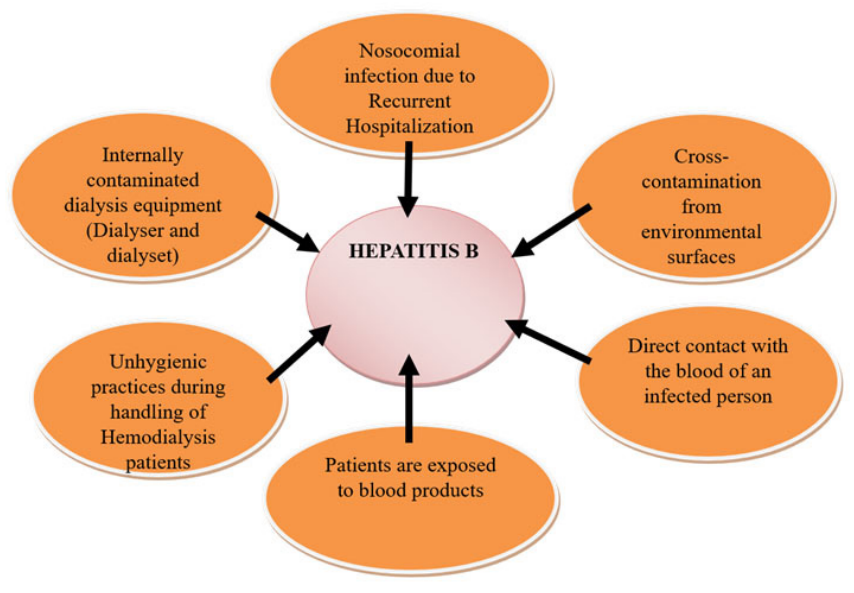

Figure 1: Mode of transmission of Hepatitis -B patient with chronic kidney disease. ${ }^{9}$

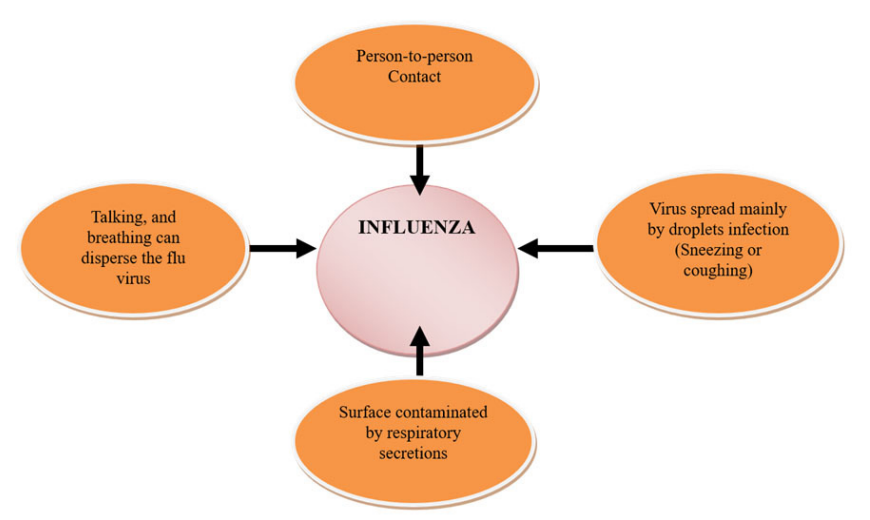

Figure 2: Mode of transmission of Influenza virus a patient with chronic kidney disease. ${ }^{1,9}$
Pneumococcal disease is spread by droplets i.e sneezing, coughing.

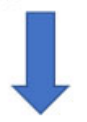

Colonize in the respiratory tract<smiles>CC1CC1C1CC1C1CC1</smiles>

Bacterial infection in the lungs can cause pneumonia i.e inflammation of lungs.

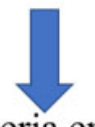

Pneumococcal bacteria enter in the bloodstream can cause blood infection i.e septicemia

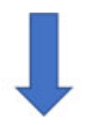

Leading poor blood flow and organ will damage

Figure 3: Mode of transmission of Pneumonia a patient with chronic kidney disease. ${ }^{1,11}$

Table 1: Average cost of commonly recommended doses of complete vaccination in adult patients suffering from chronic kidney disease. ${ }^{13,17}$

$\begin{array}{llll}\text { Sr. No } & \text { Vaccine } & \text { Average cost } & \text { The average cost of the vaccine for total doses } \\ 1 & \text { Hepatitis-B } & \text { Rs. 60-100 } & \text { Rs. } 400 \\ 2 & \text { Rs. 800-900 } & \text { Rs. } 900 \\ 3 & \text { Rs. 1400-1750 } & \text { Rs. 3500 } \\ & \text { Pneumococcal Vaccine } & & \\ & \text { PCV-13 (Pneumococcal conjugate } & & \\ & \text { vaccine-13) } & & \\ & \text { PPSV- 23 (Valent pneumococcal } & & \\ & \text { polysaccharide vaccine 23) }\end{array}$


Table 2: Recommendations for all vaccines in chronic kidney disease patients..$^{8,9,12}$

\begin{tabular}{|c|c|c|c|c|}
\hline Vaccine & Age & Dose & $\begin{array}{l}\text { Vaccination schedule/ } \\
\text { route of administration }\end{array}$ & Booster doses \\
\hline \multirow[t]{2}{*}{ Hepatitis B } & $\geq 20$ years & $40 \mathrm{mcg}$ & $\mathrm{o}, 1,2$, and 6 months/IM & Yes, when anti-HBs $<10 \mathrm{UI} / 1$ \\
\hline & $<20$ years & $10 \mathrm{mcg}$ & $\mathrm{o}, \mathrm{1}$, and 6 months/IM & Yes, when anti-HBs $<10$ UI/l \\
\hline Pneumococcal & Refer Table :3 & & & \\
\hline \multirow[t]{3}{*}{ Influenza } & $3-8$ years & $15 \mu \mathrm{g}$ & Each year/IM & No \\
\hline & 9-12 years & $15 \mu \mathrm{g}$ & Each year/IM & No \\
\hline & $>12$ years & $15 \mu \mathrm{g}$ & Each year/IM & No \\
\hline Varicella & 1-12 years & $0.5 \mathrm{ml}$ & One single dose/SC & No \\
\hline Hepatitis A & $>17$ years & $1440 \mathrm{U}$ & o, 6-12 months/IM & No \\
\hline $\begin{array}{l}\text { Measles, mumps and } \\
\text { rubella }\end{array}$ & $>18$ years & $0.5 \mathrm{ml}$ & One single dose/SC & No \\
\hline Inactivated poliovirus & $<18$ years & $0.5 \mathrm{ml}$ & $\begin{array}{l}\text { Three doses with an } \\
\text { interval of } 1-2 \text { months }\end{array}$ & $\begin{array}{l}\text { No (revaccination } 1 \text { year } \\
\text { after } \\
\text { the third dose) }\end{array}$ \\
\hline $\begin{array}{l}\text { Diphtheria and tetanus } \\
\text { toxoids }\end{array}$ & 7 years & $0.5 \mathrm{ml}$ & Three doses/IM & No \\
\hline
\end{tabular}

IM: Intramuscular, SC: Subcutaneous

Table 3: Recommendation for administering PCV13 and PPSV23 vaccines for patients with chronic kidney disease. ${ }^{23,24}$

\begin{tabular}{|c|c|c|}
\hline \multirow[b]{2}{*}{ Vaccine history } & \multicolumn{2}{|c|}{ Infants and children (ages 0-18) } \\
\hline & & Recommended regimen \\
\hline $\begin{array}{l}\text { Never vaccinated with } \mathrm{PCV}_{7} \text { or } \mathrm{PCV}_{13} \\
\text { up to } \\
\text { Age }\end{array}$ & $\begin{array}{l}\text { Routine vaccination for } \\
\mathrm{PCV}_{13}(4 \\
\text { dose series })\end{array}$ & $\begin{array}{l}\text { Administer } 1 \text { dose of PPSV } 23 \text { at } \\
\text { age } \geq 2 \text { years and } \geq 8 \text { weeks after } \\
\text { last indicated dose of } P C V_{13}\end{array}$ \\
\hline $\begin{array}{l}\text { Completed all recommended doses of } \\
\mathrm{PCV}_{7}\end{array}$ & $\begin{array}{l}\text { Administer } 1 \text { dose of } \mathrm{PCV}_{13} \\
\geq 8 \text { weeks later }\end{array}$ & $\begin{array}{l}\text { Administer } 1 \text { dose of PPSV } 23 \text { at } \\
\text { age } \geq 2 \text { years and } \geq 8 \text { weeks after } \\
\text { last indicated dose of PCV13 }\end{array}$ \\
\hline $\begin{array}{l}\text { Children aged } 24-71 \text { months who re- } \\
\text { ceived } \\
<3 \text { doses of } \mathrm{PCV}_{7} \text { before age } 24 \text { months }\end{array}$ & $\begin{array}{l}\text { Administer } 2 \text { doses of } \\
\text { PCV } 13 \\
\text { now }\end{array}$ & $\begin{array}{l}\text { Administer } 1 \text { dose of PPSV } 23 \geq 8 \\
\text { weeks later after last indicated } \\
\text { dose of } \mathrm{PCV}_{13}\end{array}$ \\
\hline $\begin{array}{l}\text { Children aged } 24-71 \text { months who } \\
\text { received any incomplete schedule of } 3 \\
\text { doses of } \mathrm{PCV}_{7} \text { before age } 24 \text { months }\end{array}$ & $\begin{array}{l}\text { Administer } 1 \text { dose of } \mathrm{PCV}_{13} \\
\text { now }\end{array}$ & $\begin{array}{l}\text { Administer } 1 \text { dose of PPSV } 23 \geq 8 \\
\text { weeks later }\end{array}$ \\
\hline $\begin{array}{l}\text { Completed all recommended doses of } \\
\text { PCV13 }\end{array}$ & $\begin{array}{l}\text { Administer } 1 \text { dose of } \\
\text { PPSV } 23 \\
\text { at age } \geq 2 \text { years and } \geq 8 \\
\text { weeks } \\
\text { after last indicated dose of } \\
\text { PCV }_{13}\end{array}$ & $\begin{array}{l}\text { Administer } 1 \text { dose of PPSV } 23 \\
\text { after } 5 \text { years }\end{array}$ \\
\hline $\begin{array}{l}\text { Children aged 6-18 years who have not } \\
\text { received } \\
P_{C V_{13}}\end{array}$ & $\begin{array}{l}\text { Administer } 1 \text { dose of } \mathrm{PCV}_{13} \\
\text { now }\end{array}$ & - \\
\hline
\end{tabular}

\section{Age 19-64 year}

Never vaccinated with $\mathrm{PCV} 13$ or PPSV23

$\begin{array}{ll}\text { Administer } 1 \text { dose of } \mathrm{PCV}_{13} & \begin{array}{l}\text { Administer } 1 \text { dose of PPSV23 } \\ \text { now }\end{array}\end{array}$

Administer 1 dose of PPSV23 after 5 years

Administer 1 dose of PPSV 23 after 5 years

Administer 1 dose of PPSV 23 after 5 years

Administer 1 dose of PPSV23 5 year after

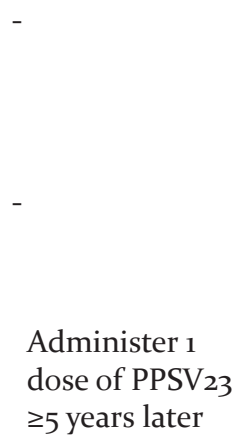


Table 3: (Continued)

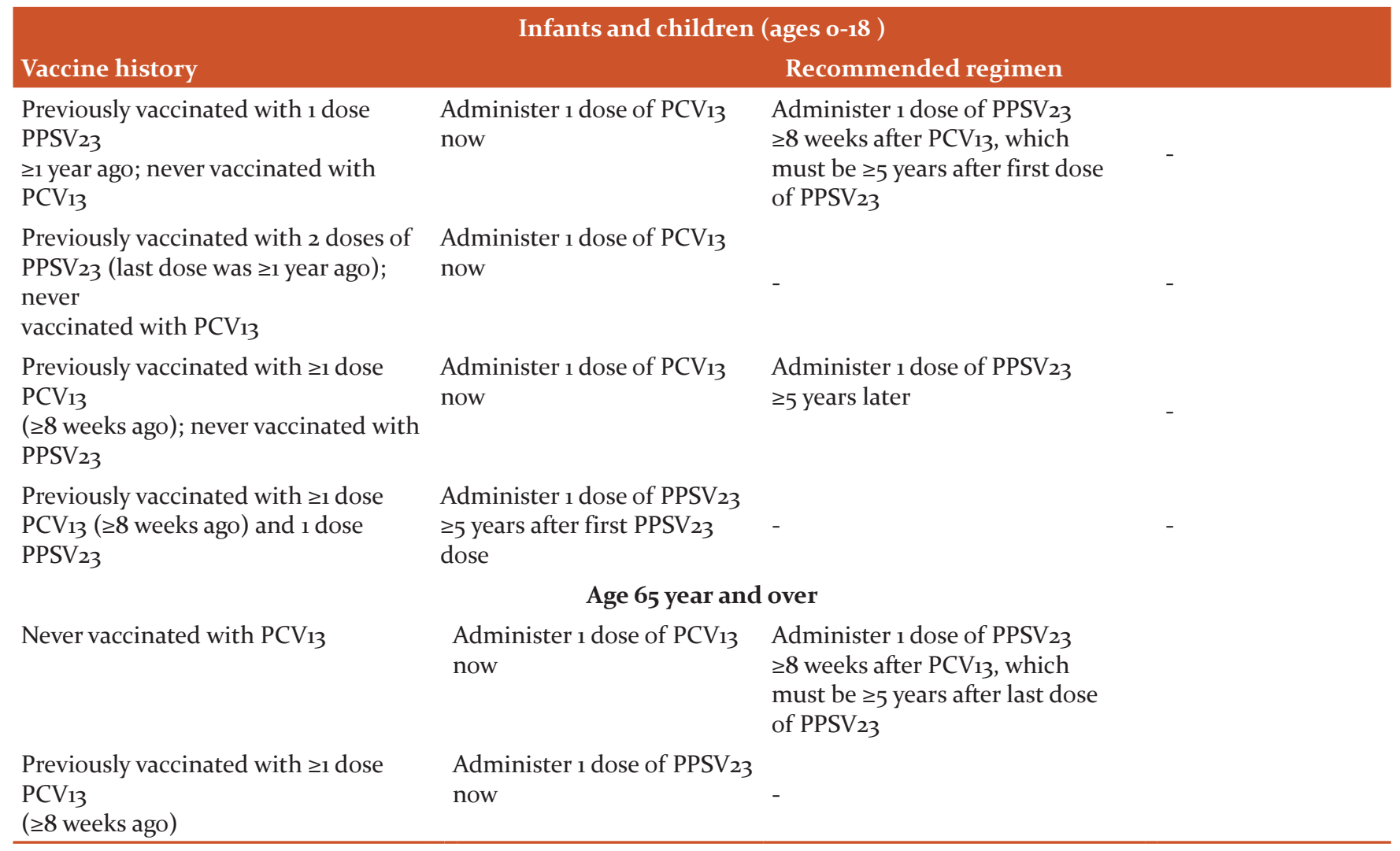

